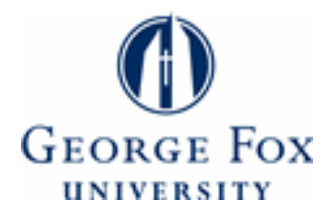

Digital Commons@ George Fox University

College of Christian Studies

2013

\title{
The Fate and Power of Heroic Bones and the Politics of Bone Transfer in Ancient Israel and Greece
}

Brian R. Doak

George Fox University, bdoak@georgefox.edu

Follow this and additional works at: http:/ / digitalcommons.georgefox.edu/ccs

Part of the Biblical Studies Commons, and the Near Eastern Languages and Societies Commons

\section{Recommended Citation}

Doak, Brian R., "The Fate and Power of Heroic Bones and the Politics of Bone Transfer in Ancient Israel and Greece" (2013). College of Christian Studies. Paper 1.

http://digitalcommons.georgefox.edu/ccs/1 


\title{
The Fate and Power of Heroic Bones and the Politics of Bone Transfer in Ancient Israel and Greece*
}

\author{
Brian R. Doak \\ George Fox University
}

\section{Introduction}

Tucked away in the Hebrew Bible at the end of 1 Samuel and then resumed near the end of 2 Samuel is a provocative tale recounting the final fate of Saul, Israel's first king. ${ }^{1}$ At the beginning of this two-part narrative (1 Sam 31:1), we find Saul atop Mount Gilboa, badly wounded by Philistine archers and nearly dead. Fearing the Philistine armies will rush upon him and continue the humiliation-perhaps by stabbing him repeatedly while still alive, as Saul suggests in 31:4, or something

\footnotetext{
* This paper was first presented in abbreviated form as part of a Society for Ancient Mediterranean Religions panel on "Civil Strife and Ancient Mediterranean Religions," at the annual meeting of the Society of Biblical Literature, Atlanta, Ga., November 22, 2010, and I am very grateful for the comments I received in this forum. I would also like to thank Song-Mi Suzie Park (Austin Presbyterian Theological Seminary) and Suzanne Smith (Harvard University) for reading an earlier draft of this paper and giving useful suggestions for its improvement, as well as Barbara McCauley (Concordia College) for providing me with a hard copy of her article on bone transferal. Finally, I owe many thanks to an uncommonly helpful anonymous reviewer (a classicist), who provided many specific suggestions that I have followed.

${ }^{1}$ Note that 1 Chr 10:1-14 partly parallels 1 Sam 31:1-13; the Chronicler's account is basically similar, except for a few details, but ends with the acts of Jabesh Gilead in re-taking Saul's body and burying the bones beneath a tree. Saul Zalewski argues that the Chronicler has presented the story in such a way as to make clear that Saul was executed by God directly, as opposed to dying by the fault of David ("The Purpose of the Story of the Death of Saul in 1 Chronicles X," VT 39 [1989] 449-67). For recent essays on Saul's place within the Deuteronomistic history, see Saul in Story and Tradition (ed. Carl S. Ehrlich and Marsha C. White; FAT 47; Tübingen: Mohr Siebeck, 2006) and the bibliography cited therein, as well as the relevant sections in P. Kyle McCarter's commentary on 1-2 Samuel: $I$ Samuel (AB 8; Garden City, N.Y.: Doubleday, 1980) 439-44; II Samuel (AB 9; Garden City, N.Y.: Doubleday, 1984) 436-46. According to McCarter, the Chronicles passage "seems to hark back to a shorter, more primitive version" of the story, which I agree is possible (1 Samuel, 440).
} 
worse ${ }^{2}$ - Saul commits suicide. As the rest of the chapter recounts, upon finding his corpse, the enemy army abuses him in a different but perhaps not less dreadful manner, i.e., by beheading the king and hanging the remainder of his body on the wall of Beth Shan (along with the bodies of his sons, who died with their father in the battle). The residents of Jabesh Gilead, however, hear of these events and abscond with the bodies, burying the bones in their own territory and thus ending this particular episode of conflict between Israel and Philistia.

The story does not end here, however, as the international context gives way to inter-Israelite strife in the second part of the drama. Saul's past mistreatment of the Gibeonites (not described in the biblical text) comes back to haunt his family: we are informed that a three-year famine during the time of King David came as the result of Saul's attempt to annihilate these non-Israelites who had nonetheless lived peacefully within Israel's borders (see Joshua 9). The solution to this famine-initiated by David and carried to fruition by the Gibeonites-is to impale seven of Saul's sons, resulting in a grisly mountaintop scene (2 Sam 21:9) mirroring the site of Saul's death along with his own heirs in battle. Rizpah, mother of two of the impaled sons of Saul, proceeds to hold a long vigil over the bodies, prompting David to reclaim the bones of Saul and Jonathan from Jabesh Gilead and re-bury them in the tomb of Saul's family in the land of Benjamin. Only after this bone transferal is accomplished do the famine and its accompanying bloody conflict come to an end.

There are many odd and noteworthy features of this story, just as Saul's place within the narratives of 1-2 Samuel is shot through with the marks of divine election, un-election, loopholes, disaster, and redemption. All of this suggests a deep and creative ambivalence regarding the status of Saul as king and casts a series of questions over his final place in the narrative. ${ }^{3}$ To put a turn on a phrase, throughout 1 Samuel the narrator seems repeatedly to praise Saul by faint damnation, presenting his disqualification from kingship through a series of infractions that seem trivial or unfair, while at the same time damning him (and eventually, several of his sons) nonetheless. Indeed, Saul seems to embody

\footnotetext{
${ }^{2}$ The verb used here, התעלל appears several other times in the Bible, e.g., in reference to the way YHWH made a mockery of Egypt during the Exodus (Exod 10:2; 1 Sam 6:6); to describe the abuse that accompanies a violent gang rape (Judg 19:25); and in the mouths of kings worried about what invading armies will do with their bodies (here, with a parallel in $1 \mathrm{Chr}$ 10:4, and Jer 38:19). Cf. Num 22:29; Ps 141:4, where the action seems less severe or specific.

${ }^{3}$ See David M. Gunn, The Fate of King Saul: An Interpretation of a Biblical Story (JSOTSup 14; Sheffield, U.K.: JSOT, 1989); Diana V. Edelman, "Saul ben Kish in History and Tradition," in The Origins of the Ancient Israelite States (ed. Volkmar Fritz and Philip R. Davies; JSOTSup 228; Sheffield, U.K.: Sheffield Academic Press, 1996) 142-59; and V. Philips Long, The Reign and Rejection of King Saul: A Case for Literary and Theological Coherence (SBLDS 118; Atlanta, Ga.: Scholars Press, 1989). My thinking on Saul in 1-2 Samuel has also recently been influenced by Song-Mi Suzie Park, "Saul's Spiritual Torment in 1 Samuel 16:14: Conflicts in the Royal, National, and Divine Psyche," a paper presented at the annual meeting of the Society of Biblical Literature, New Orleans, La., November 2009.
} 
a distinctly tragic pathos, and there have been limited but notable attempts to imagine him along the lines of Greek models-either as a figure in a Hebrew tragedy ${ }^{4}$ or as a full-blown Mediterranean "hero." 5

Following in this tradition of comparative studies linking Saul with Greek heroic themes, in this paper I attempt to read the narratives recounting the fate of Saul's body in light of what is known about heroic relics-specifically the bones of the hero-and the politics of hero cults in the Iron Age Western Mediterranean. Saul's status as an Israelite hero is a hitherto underexplored lens through which to investigate the meaning and power of Saul's dead body, and I shall argue that by comparing the biblical account of the transferal of Saul's bones with classical Greek texts of heroic bone transfer, we are able to see the political import of David's actions in the Bible more clearly and thus better understand the dynamics of civil strife in this disconcerting text. There have been no attempts, as far as I know, to compare this or any other tale of bone transfer within the Hebrew Bible with the very well-known phenomenon of heroic bone transfer in ancient Greece. Moreover, there seem to be equally few studies of the way body parts or other physical items are conceived of as relics or objects of power in the Hebrew Bible, and by considering Saul's bones as just such objects I hope to make a contribution to this realm of scholarship.

\footnotetext{
${ }^{4}$ This line of comparison is taken up, e.g., by Sarah Nicholson, Three Faces of Saul: An Intertextual Approach to Biblical Tragedy (JSOTSup 339; London: Sheffield Academic Press, 2002); J. Cheryl Exum, Tragedy and Biblical Narrative: Arrows of the Almighty (Cambridge, U.K.: Cambridge University Press, 1992) 70-119; Thomas R. Preston, "The Heroism of Saul: Patterns of Meaning in the Narrative of the Early Kingship," JSOT 24 (1982) 27-46; and Yairah Amit, "The Delicate Balance in the Image of Saul and Its Place in the Deuteronomistic History," in Saul in Story and Tradition, 71-79, esp. 71-72 and references there.

${ }^{5}$ Preston argues that Saul emerges as the true "hero" vis-à-vis David, due, in part, to his "heroic death" on the battlefield ("Heroism of Saul," 27-28, 33, 36-37, 42-43). W. Lee Humphreys sees an older version of the Saul story that bears Aegean influence and presents a truly "heroic" Saul ("From Tragic Hero to Villain: A Study of the Figure of Saul and the Development of 1 Samuel," JSOT 22 [1982] 92-117, at 106). See also Humphreys's earlier comments in "The Tragedy of King Saul: A Study in the Structure of 1 Samuel 9-31," JSOT 6 (1978) 18-27 and in "The Rise and Fall of King Saul: A Study of an Ancient Narrative Stratum in 1 Samuel," JSOT 8 (1980) 74-90. In this latter article especially, Humphreys compares Saul with specific Greek heroic motifs, but not bone transfer ("Rise and Fall," 83-87). Gregory Mobley finds in Saul "a full range of heroic attributes: demonstrated valor (1 Sam 11:5-11; 14:20-23, 47-48), martial rage (1 Sam 11:5), the 'breath of YHWH/Elohim' (1 Sam 10:6, 9; 11:6; 19:23), a signature weapon (his spear; 1 Sam 13:22; 18:10; 19:9; 20:33; 22:6; 26:7, 11, 12, 16, 22; 2 Sam 1:6), and even (perhaps) a special birth (1 Samuel 1)" ("Glimpses of Heroic Saul," in Saul in Story and Tradition, 80-87, at 80). This last attribute, a special birth, would assume that Samuel's birth narrative was originally that of Saul but was intentionally stolen from the king and applied to the prophet as a way of further marginalizing Saul (an idea first proposed in the 1932 Uppsala dissertation of Ivar Hylander, Der literarische Samuel-Saul-Komplex (1 Sam. 1-15). Traditionsgeschichtlich untersucht [Uppsala: Almqvist \& Wiksell, 1932]).
} 


\section{Interpretations and Sources}

Before proceeding to an examination of selected Greek stories of bone transfer, in combination with a more detailed examination of our Saul narrative on this front, I would like briefly to review something of the history of scholarship devoted to the specific biblical passages at hand. In the late nineteenth- and early twentiethcentury theological context, several scholars seized upon the gruesome weirdness of the solution to the famine in the second part of our story, either to apologetically quell concerns that the story evinces some demonic vengeance or, alternatively, to highlight and promote these exact features as evidence of the benefit of historical criticism in pointing up "primitive" features of a bygone layer of Israelite religion represented in the killings. ${ }^{6}$

Modern studies have continued to focus on various religious or legal aspects of the scene in 2 Sam 21:10-14 involving Rizpah and David's bone transfer. ${ }^{7}$ Saul Olyan has illuminatingly analyzed the actions of the Gileadites in terms of honor and shame categories played out through the socio-legal sphere of covenant relationships, as well as the concept of burial at the patrimonial tomb; ${ }^{8}$ David's acts of re-burial in 2 Sam 21:11-14 echo an earlier scene in 2 Sam 4:12, where David had previously interred a Saulide heir, Ish-bosheth, in a family grave. ${ }^{9}$ Mark Hamilton has recently begun a discussion about Saul's royal body, both physical

\footnotetext{
${ }^{6}$ One can see something of both of these tendencies in William G. Jordan, "Homiletics and Criticism: II Samuel 21:1-14," The Biblical World 33 (1909) 32-37. Regarding the famine and human sacrifice, we may note that this story belongs to a rather limited corpus of texts in the Hebrew Bible wherein there seems to be a "magical" or otherwise extraneous (to Israel's deity) force in operation; one other example is 2 Kings 3, where human sacrifice unleashes a mysterious "wrath" (קצ) against Israel.

${ }^{7}$ Essays discussing the specific religious or legal factors at play in the text are numerous, including three studies published in 1955 by different authors: Henri Cazelles, "David's Monarchy and the Gibeonite Claim," PEQ 87 (1955) 165-75; Arvid S. Kapelrud, "King and Fertility: A Discussion of II Sam 21:1-14," NTT 56 (1955) 113-22; Abraham Malamat, "Doctrines of Causality in Biblical and Hittite Historiography: A Parallel," VT 5 (1955) 1-12. This is not to mention analyses in various commentaries, some of which I cite elsewhere in this study. See also Ze' ev Weisman, "Legal Aspects of David's Involvement in the Blood-Vengeance of the Gibeonites," Zion 54 (1989) 149-60 [in Hebrew], and, on the issue of a covenant with Gibeon alluded to in 2 Sam 21:1-7, see the major study of Joseph Blenkinsopp, Gibeon and Israel: The Role of Gibeon and the Gibeonites in the Political and Religious History of Early Israel (Cambridge, U.K.: Cambridge University Press, 1972) and the literature cited therein. On the role of Rizpah in the narrative, see Niek Poulssen, "An Hour with Rispah: Some Reflections on II Sam. 21,10," in Von Kanaan bis Kerala. Festschrift für Prof. Mag. Dr. Dr. J. P. M. van der Ploeg O.P. zur Vollendung des siebzigsten Lebensjahres am 4. Juli 1979; überreicht von Kollegen, Freunden und Schülern (ed. Johannes P. M. van der Ploeg and Wilhelm C. Delsman; AOAT 211; Neukirchen-Vluyn: Neukirchener Verlag, 1982) 185-211. For an extended bibliography on this front, from which I learned of some of the studies listed here, see Simeon Chavel, "Compositry and Creativity in 2 Samuel 21:1-14," JBL 122 (2003) 23-52, at 24 n. 4.

${ }^{8}$ Saul M. Olyan, "Honor, Shame, and Covenant Relations in Ancient Israel and Its Environment," JBL 115 (1996) 201-18, at 214-15.

${ }^{9}$ Saul M. Olyan, "Some Neglected Aspects of Israelite Interment Ideology," JBL 124 (2005) $601-16$, at 605,612 .
} 
and metaphorical, pointing out the ways in which "royal bodies reflect the culture's ideas, values, hopes, and fears, in short, its cosmology."10

In a very thorough and mostly convincing investigation, Simeon Chavel has conducted an "internal literary analysis" of the passage, focusing on the sourcecritical problem instead of the supposed literary "unity" of the chapter suggested by its appearance at the end of 2 Samuel. ${ }^{11}$ Chavel identifies two sources-one in 2 Sam 21:1-11,13a, and 14b and the other in vv. 12,13b, and 14a-and points to the seemingly "alternate set of assumptions and approaches" to the dead bodies in each source: in the former narrative, David and Saul stand in antagonistic terms, with David's vow contravening Saul's quest to annihilate the Gibeonites-instead, Saul's descendants are shamed; in the latter source, David, "in the throes of his attempt to establish his credentials as king,"12 acts with loyalty toward Saul. The source in which the Gibeonites are featured resonates with themes and vocabulary appearing throughout 2 Samuel 2-6, while the bone transfer story has nothing to do with the Gibeonites and rather seems to continue the narrative in 1 Sam 31:818, where Saul's bones are stolen in the first place. ${ }^{13}$ For Chavel, David's calm and controlling command over the transfer of the Saulide heirs to the Gibeonites betrays a situation in David's reign after David has assumed total control of the country, whereas the bone transfer story—which uses David's personal name (דוד) and never "the king" (המלך), unlike the other source, which uses both—reflects a situation wherein the author is still trying to show David's careful involvement in not looking like a villain who takes advantage of Saul's misfortune for his own advancement. ${ }^{14}$ For Chavel, the text as we have it in 2 Sam 21:1-14 not only exhibits internal discontinuities, but the reference to the bone transfer is out of step with the earlier narrative action in 1 Samuel 13, wherein Saul seems to be buried with some finality. ${ }^{15} \mathrm{I}$ will return to this seeming dichotomy of tones later in this study, but suffice it to say that, on thematic grounds, and particularly on the basis of the bone transfer accounts by which I will analyze this text, there is no

\footnotetext{
${ }^{10}$ Mark W. Hamilton, "The Creation of Saul's Royal Body: Reflections on 1 Samuel 8-10," in Saul in Story and Tradition, 139-55, at 141. Though Hamilton's study focuses on the "shaping" of Saul's body in 1 Samuel 8-10 toward its use for leading Israel and reflecting YHWH's divine rule, we should expand some of these categories and their application to the continued meaning of Saul's body in his post-mortem appearances. See also the brief discussion of Saul's second burial in 2 Sam 21:13-14 in Hamilton's The Body Royal: The Social Poetics of Kingship in Ancient Israel (Biblical Interpretation Series 78; Leiden: Brill, 2005) 168-69. On Saul and royal ancestral cult, note also Francesca Stavrakopoulou, Land of Our Fathers: The Roles of Ancestor Veneration in Biblical Land Claims (LHB 473; London: T\&T Clark, 2010) 114-15.

${ }^{11}$ Chavel, "Compositry and Creativity." Julius Wellhausen first suggested this putative unity via the palistrophe in 2 Samuel 21-24; see Die Composition des Hexateuchs und der historischen Bücher des alten Testaments (3d ed.; Berlin: Reimer, 1899) 260-61 (cited in Chavel, "Compositry and Creativity," 23 n. 2).

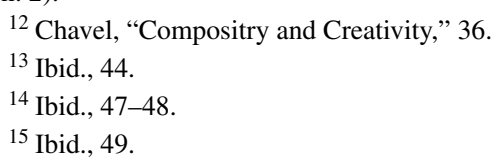


strong reason to accept that David's actions in either supposedly discrete "source" stand in clear contradiction to the other, even if we find in this narrative a push and pull of conflicting motivations and political calculation.

\section{Heroic Bone Transfer in the Western Mediterranean and Beyond}

Indeed, stories of the relocation of important bodies are fraught with indications that these bone transferals are transactions of political power, as demonstrated by several well-known examples in classical Greek texts. Narratives of heroic bone transfer in the Western Mediterranean appear in a variety of sources, as texts spanning from Herodotus through the Roman period contain no less than thirteen different examples of this distinct and (nearly) formally uniform type of account. ${ }^{16}$ In these stories, we find a generic pattern of action: a population learns via oracle that heroic bones are needed to secure some benefit; the bones are then procured, either by a miraculous discovery, by a clue from the oracle, or by outright theft; and the subsequent transfer of the bones to the city in need brings victory or some other blessing. ${ }^{17}$ Since the religious importance of bone transfer deeply relies upon, and interacts with, notions of hero cult generally, and since the religious power of the hero cult relies upon both a political claim to legitimation and personal, spiritual benefits to the citizenry, ${ }^{18}$ I find the debate regarding whether the bones

\footnotetext{
${ }^{16}$ I derive this specific number from Barbara McCauley, "Heroes and Power: The Politics of Bone Transferal," in Ancient Greek Hero Cult: Proceedings of the Fifth International Seminar on Ancient Greek Cult, Organized by the Department of Classical Archaeology and Ancient History, Göteborg University, 21-23 April 1995 (ed. Robin Hägg; Skrifter utgivna av Svenska institutet i Athen $8^{\circ}$ 16; Stockholm: Svenska Institutet i Athen, 1999) 85-98, at 96 (see n. 40 on the same page for a list of these thirteen examples). For my analysis of Greek and Latin accounts of bone transferal, I rely on McCauley's thorough treatment of the issue, as well as on: Carolyn Higbie, "The Bones of a Hero, the Ashes of a Politician: Athens, Salamis, and the Usable Past," Classical Antiquity 16 (1997) 278-307, esp. 296-301; Anthony J. Podlecki, “Cimon, Skyros, and 'Theseus' Bones',” JHS 19 (1971) 141-43; and the bibliography and examples provided in these studies. Note also the older but still useful study of Friedrich Pfister, Der Reliquienkult im Altertum (Religionsgeschichtliche Versuche und Vorarbeiten 5; Giessen: Töpelman, 1909-1912; repr., Berlin: de Gruyter, 1974).

${ }^{17}$ McCauley, "Heroes and Power," 96.

${ }^{18}$ On hero cult, see recently Mensch-Heros-Gott. Weltentwürfe und Lebensmodelle im Mythos der Vormoderne (ed. Christine Schmitz and Anja Bettenworth; Stuttgart: Steiner, 2009). For archaeological data, see Carla M. Antonaccio, An Archaeology of Ancestors: Tomb Cult and Hero Cult in Early Greece (Greek Studies; Lanham, Md.: Rowman \& Littlefield, 1995); eadem, "Contesting the Past: Hero Cult, Tomb Cult, and Epic in Early Greece," AJA 98 (1994) 389-410; and for textual reflexes, Gregory Nagy, The Best of the Achaeans: Concepts of the Hero in Archaic Greek Poetry (rev. ed.; Baltimore: Johns Hopkins University Press, 1999) 67-210. The "mystical," personal aspects of hero cult are clearly evident, for example, in Philostrotus's On Heroes, on which see Gregory Nagy, "The Sign of the Hero: A Prologue to the Heroikos of Philostratus," in Flavius Philostratus, Heroikos (trans. Ellen Bradshaw Aitken and Jennifer K. Berenson Maclean; Writings from the Greco-Roman World 1; Atlanta, Ga.: Society of Biblical Literature, 2001) xv-xxxv. This is not to mention the varieties of healer ideologies attached to cults of heroes, for which see Wolfgang Speyer, "Heros," $R A C$ 14 (1988) 861-77, esp. 870; and Lewis R. Farnell, Greek Hero Cults and Ideas of Immortality: The
} 
themselves as physical objects were thought to contain some sort of numinous power-as opposed to viewing them only as "symbolic" political tokens- to be misguided, insofar as the two views are presented as mutually exclusive. ${ }^{19}$ Clearly both dynamics were in play whenever the bodies of heroes were involved.

The parade example of heroic body movement in classical literature is the latefifth-century Sophoclean Oedipus cycle, where the fate of heroic bones is a standing concern through a three-part dramatic movement (Oedipus Tyrannus, Oedipus at Colonus, Antigone). The second part of this drama, Oedipus at Colonus, is of primary significance for our discussion here, since the final resting place of Oedipus's heroic body - the object of both intense horror and powerful reverence-is the central narrative concern. ${ }^{20}$ Having become a pariah to Thebes, his homeland, Oedipus travels a path from curse to blessing, from ritual pollution to stability and welcome in a new home (near Athens). The power of the body (highlighted, e.g., in Oed. col. 385) has implications for Oedipus's homeland, as various claimants to the throne of Thebes, such as Creon, wish to commandeer Oedipus's dangerous body as a boon for their own political ventures. Indeed, Creon seeks to bring Oedipus near-but not into-Thebes, so as to avoid an oracular pronouncement stating that the Theban army would suffer a defeat if Oedipus were to be buried outside of his hometown. Oedipus rejects Creon's efforts, and, conversely, assures Creon that his spirit will act as an agent of harm toward those who had once rejected him (Oed. col. 765-784). Thus we see the power of the heroic body, in conjunction with an oracular threat combined in a narrative, demonstrated through the body of the figure who is perhaps the most compelling locus of ritual and political ambivalence of all heroic actors in Greek drama.

More succinct examples of bone transfer occur in Herodotus (Hist. 1.66-68), where we learn of the theft and transfer of Orestes's bones from Tegea to Sparta, and in Plutarch, regarding the movement of Theseus's bones from Skyros to Athens (Thes. 36.1-2; Cim. 8.3-6). The political crises addressed by the bone transferal vary; most common are battles-e.g., the Trojan War apparently could not end until the shoulder blade of Pelops was brought to the Greeks (Pausanias, Descr. 5.13.4 $)^{21}$-or rival territorial claims. Other transfers occur as the result of oracular instruction specifically for blessing (e.g., Hector's bones brought from Ilium to Thebes [Descr. 9.18.5]) or from seemingly unmotivated Delphic commands (as in Descr. 8.9.3-4). One particularly extended account, recorded by Pausanias, tells of

Gifford Lectures Delivered in the University of St. Andrews in the Year 1920 (Oxford: Clarendon Press, 1921) 150-51, 234-79.

${ }^{19}$ McCauley argues against the view that bones were considered as talismans or "magic" objects in their own right ("Heroes and Power," 94).

${ }^{20}$ See, e.g., Darice Birge, "The Grove of the Eumenides: Refuge and Hero Shrine in Oedipus at Colonus," Classical Journal 80 (1984) 11-17; and Andreas Markantonatos, Oedipus at Colonus: Sophocles, Athens, and the World (Untersuchungen zur antiken Literatur und Geschichte 87; Berlin: de Gruyter, 2007) 140-66.

${ }^{21}$ Pausanias records bone transfers with distinct interest and frequency. 
the transfer of Hesiod's bones in a time of disaster, which I quote here because it is a lesser-known story and because of the parallel motif of famine/plague followed by an oracle and bone relocation found in 2 Sam 21:1-14:

And there are graves of Minyas and Hesiod. They say that they recovered the bones of Hesiod in the following way. A plague had fallen on man and beast, so they sent envoys to the god. The Pythian priestess, they say, answered the envoys that their only remedy was to bring back the bones of Hesiod from the land of Naupactus to the land of Orchomenus. The envoys next inquired in what part of the Naupactian territory they should find the bones, and the Pythian priestess answered them again that a crow would show them the spot. So when the messengers had landed, they saw, it is said, a rock not far from the road with the bird perched on it; and they found the bones of Hesiod in a cleft of the rock. (Descr. 9.38.3) $)^{22}$

Common to so many of these references (but lacking from the account just cited) are the distinct political motivations of those who find, reclaim, or steal the heroic bodies. In the case of the Spartan theft of Orestes's bones, regional territorial claims over and against Tegea were at stake, as well as genealogical legitimation for the historically late-coming Spartans. For the Athenian statesman Cimon, commandeering the bones of Theseus, patron hero of Athens, was an extremely popular move among the citizenry, if not a bald act of deception for his own political advantage; by bringing Theseus's bones to Athens, Cimon was simultaneously drawing on the association of the supposed miraculous appearance of Theseus at the battle of Marathon to lead the Greeks to victory and on his own father's notable role in the same battle. ${ }^{23}$ As McCauley rightly argues, these bone transfers function on many levels, and, as crass as the political manipulation may appear in any given account, we should not think we have exhausted the meaning of the act by only applying the reductionist category of "propaganda" and simply moving on; ancient actors-both leaders and broader audiences-seem to have deeply believed in the religious and psychological power of these acts. ${ }^{24}$

The politically charged reclamation and movement of bones is, of course, not only an ancient phenomenon, as many examples could show; one recent and compelling anecdote may suffice. ${ }^{25}$ On December 17, 2007, the anniversary of Venezuelan hero Simón Bolívar's death (in 1830), president Hugo Chávez

${ }^{22}$ Translation from Pausanias, Description of Greece (trans. James G. Frazer; 6 vols.; London: Macmillan, 1913) 1:491.

${ }^{23}$ See the discussion in McCauley, "Heroes and Power," 90-91.

${ }^{24}$ Ibid.

${ }^{25}$ Information here taken from "TB or not TB: Venezuela's President Buries Bad News by Disinterring a National Icon," The Economist (July 22, 2010) 40. The phenomena of relic transfer and bone reclamation persisted through many societies and seemingly all eras; for an insightful study, see Patrick J. Geary, Furta Sacra: Thefts of Relics in the Central Middle Ages (Princeton, N.J.: Princeton University Press, 1990). As Geary points out, a relic must somehow be identified as such, whether by a marked tomb, a temple, or some other context-which could include written or oral tradition (ibid., 5-7). The biblical account of the theft of Saul's bones, as I discuss it in this essay, thus stands 
suggested that Bolívar was murdered and did not die of tuberculosis, as had always been thought. This charge of assassination carried with it a loaded political parallel for Chávez, as the then-current president, stymied with economic woes and waning popular appeal, first announced his theory just days after a major referendum defeat (on constitutional reform). ${ }^{26}$ Ahead of the September elections in 2010, Chávez ordered the body of Bolívar to be exhumed in July, with parts of the body (skull, teeth, and vertebrae) extracted and tested for the poisoning theory. In the process of testing these body parts for authenticity, Chávez claimed that the bones of Bolívar spoke to him, confirming his identity: "Yes, it's me," Bolívar said. "That glorious skeleton must be Bolívar," Chávez wrote on his Twitter page, "for we could feel his spark." The plan for the transfer of Bolívar's body and the re-interring of the bones, which occurred during the following year's bicentennial celebrations (Venezuela declared its independence on July 5, 1811), served as a capstone to the drama: a new burial would ensure that Bolívar does not lie with various other national heroes of the past, whom Chávez disdained, in his previous grave, but rather in a new, presumably symbolically useful, location. ${ }^{27}$ The association of Bolívar's physical body with Chávez at a charged moment in the latter's career clearly demonstrates the enduring value of the heroic body as a focal point of national hopes and anxiety.

\section{Bone Transfer in the Saul Narrative}

Having discussed these examples, let us now return to the narrative of Saul's burial and re-burial. First, we should recognize that the manipulation of Saul's bones for political, or polemical, purposes is not a unique incident in the Hebrew Bible. The transferal of the bodies of Jacob and Joseph are the most famous instances of such acts (Gen 50:2-13, 25-26; Exod 13:19; Josh 24:32); Joseph's bone transfer, in particular, functions along the lines of other stories wherein the bones of a founding hero must be collected and returned to their place of origin. ${ }^{28}$ Elsewhere, bone transferal is an act of desecration, as in $2 \mathrm{Kgs} \mathrm{23:16-20,} \mathrm{where} \mathrm{we} \mathrm{find}$ the collection and burning of bones on the altar to fulfill the prophecy against

as a lasting "identification" of the tradition; it is, in a sense, the final grave marker. Moreover, Geary helpfully points to the manner in which relic theft is an act of cultural violence and meaning-making, since this kind of theft breaks the bounded, initial context of identification and replaces that context with a new one.

${ }^{26}$ I.e., the parallel, for Chávez, is that his own political opponents were attempting to "assassinate" him (either figuratively or literally).

${ }^{27}$ A friend and specialist in Venezuelan politics at the University of California, Santa Cruz, Donald V. Kingsbury, informed me recently that this exhuming did in fact occur in 2011.

${ }^{28}$ Upon his death, Jacob's bones are taken from Egypt to Canaan (see Gen 50:4-14). See comments in Moshe Weinfeld, The Promise of the Land: The Inheritance of the Land of Canaan by the Israelites (Taubman Lectures in Jewish Studies 3; Berkeley: University of California Press, 1993) 15, 34. See also the bone transfer to a patrimonial grave in 1 Macc 13:25. 


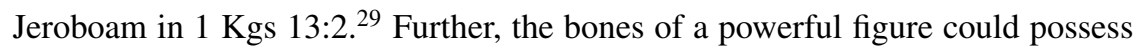
revivifying powers, such as those of Elisha, which bring a corpse to life in $2 \mathrm{Kgs}$ 13:31-32.

The narrative involving Saul's bones is particularly detailed by biblical standards and can be viewed as a two-part drama. ${ }^{30}$ The first situation of national crisis is the stolen and defiled body of the king; the second is the domestic famine. The first is easily understood in terms of national shock, as the Philistine problem is clearly about the honor of the entire country, while David's motives in the second part are somewhat more difficult to ascertain, and thus will be the main focus of my comments here.

Part One: The Gileadites transfer the body. The residents of Jabesh Gilead, who first retrieve the bodies of Saul and his sons from the wall of Beth Shan and bury them in their own territory, appear in two distinct stories in the Deuteronomistic History, both of which seem to bear importance for the present narrative. ${ }^{31}$

Jabesh Gilead makes a first inauspicious appearance in Judges 21. After the Gileadite residents fail to attend a sacred assembly at Mizpah, the tribes in attendance raise up a 12,000-man army to attack Jabesh Gilead, slaughtering men, women, and children but sparing 400 virgins from the region, whom they then offer as marriage partners for the previously shunned Benjamites. Thus, we find a putatively early (though ignominious) genealogical bond between Benjamin, which is Saul's tribe, and Jabesh Gilead. ${ }^{32}$

Later, in 1 Sam 11:1-9, Jabesh Gilead finds a reason to be zealous for Saul in particular: Saul personally rescues them from the harsh oppression of Nahash the Ammonite. This first part of the bone transfer drama, then, resounds with echoes of past tribal loyalties and political affiliations. When David learns of the actions of Jabesh Gilead in burying Saul's body (2 Sam 2:4-5), he praises them for this act and immediately tries to woo them, simultaneously announcing Saul's death and suggesting, by blessing them, that the Gileadites should accept David's

${ }^{29}$ For bone scattering, burning, or other mistreatment as desecration, see Ps 53:6; 141:7; Jer 8:1; Ezek 6:5; Amos 2:1; see also Bar 2:24.

${ }^{30}$ Many commentators assume the stories in 1 Samuel 31 and 2 Samuel 21 were originally part of a unified, congruous story, uninterrupted by so much intervening material; e.g., McCarter (II Samuel, 443) suggests that the story in 2 Sam 21:1-14 was at first omitted from what now appears in 1 Sam 31:1-13 but was later reinserted by another editor in its current place.

${ }^{31}$ See Diana V. Edelman, "Saul's Rescue of Jabesh-Gilead (1 Sam. 11.1-11): Sorting Story from History," ZAW 96 (1984) 195-209.

${ }^{32}$ Susan Niditch suggests an implicitly "anti-Saulide" polemic in this story, as Jabesh Gilead is possibly portrayed here as failing to affirm proper military unity with the rest of the nation (Judges [OTL; Louisville: Westminster John Knox, 2008] 209). Cf. Robert G. Boling, who finds the presentation of Jabesh Gilead as sympathetic, as it is "the only segment of Israel not guilty of overreacting" (Judges [AB 6A; Garden City, N.Y.: Doubleday, 1975] 292). Whatever the case, it is certainly true, as Niditch points out, that in this "foundational tale" we see "an important sacred trail," which "emphasizes national identity and maps an important means of religious self-definition. The author thereby emphasizes that the roots of Israelite identity are ancient and deep" (Judges, 210). 
kingship. ${ }^{33}$ The Gileadite response as a whole is uncertain, but the actions of the commander of Saul's army, Abner, are clear: he whisks away Saul's remaining heir in the region, Ishbaal, who then becomes king over not only Gilead but the entirety of the northern part of the country for two years (this after David had already been anointed king in Jerusalem). Consequently, we find a clear and sustained pattern of alliance between Jabesh Gilead and Saul.

Part Two: David and the bone transfer. The onset of a three-year famine (רעב) during David's reign is a social, political, and religious crisis in the extreme. ${ }^{34}$ Not only is famine a disaster of fertility regarding the land and its produce, but it is also a catastrophic symbol of the failure of monarchic rule; in Psalm 72 (vv. 1-4, 1216 in particular), for example, we are reminded of the close connection between the ideologies of fertility, justice, and kingship. When the king is upright, the people flourish, and the land produces in turn. Thus, a prolonged famine calls into question the righteous rule of the king; a famine obviously creates the devastating practical problem of starvation, but the problem ripples outward (or upward) and implicates the monarch for abdicating his role in the order of the cosmos. One midtwentieth-century interpreter, Arvid Kapelrud, seized on just these associations and suggested that the famine of 2 Sam 21:1 could only be broken by "a sacrifice of the highest rank," viz. a member of Saul's own family (presuming David was not willing to sacrifice himself or one of his own sons) ${ }^{35}$ Kapelrud further proposed that David himself may have suggested to the Gibeonites that the famine was the result of some vague transgression Saul had perpetrated against them in the past $^{36}$ - we may note again here the fact that nowhere is Saul's excessive zeal against the Gibeonites actually recorded in the Bible, though an anecdote like this may well have served the author of 1 Samuel if indeed he had such a story at his disposal. "It was only a man with the intelligence of David," Kapelrud argues, "who could get such an idea: to use the very sacredness of the royal family to get rid of its members." ${ }^{37}$ If the author were trying to cover up the idea of a royal, fertility-inducing sacrifice - as he must be if Kapelrud's interpretation is correct, since the biblical narrative gives a distinctly different reason for the slaughterthen why tell the story at all ${ }^{38}$ Whatever the specific problems with such an

${ }^{33}$ See comments in Olyan, "Honor, Shame, and Covenant," 214.

34 This may have been caused by drought (hence the possible significance of the falling rain in 2 Sam 21:10) or could signify some other problem of crop failure, infestation, or disease.

${ }^{35}$ Kapelrud makes this suggestion in two essays: "King and Fertility: A Discussion of II Sam 21:1-14," NTT 56 (1955) 113-22; and "King David and the Sons of Saul," in La regalità sacra. Contributi al tema dell'VIII congresso internazionale di storia delle religioni (Roma, aprile 1955) (SHR 4; Leiden: Brill, 1959) 294-301.

${ }^{36}$ Kapelrud, "King David," 300.

${ }^{37}$ Ibid., 301.

${ }^{38}$ McCarter refutes Kapelrud's thesis on the same grounds (II Samuel, 444). Moses Buttenwieser compares the story in 2 Samuel 21 with Greek concepts, viz. the idea that unburied bodies would haunt the living ("Blood Revenge and Burial Rites in Ancient Israel," JAOS 39 [1919] 303-21, at 
argument, we should nonetheless view this fertility failure as an important civil crisis of monarchic authority.

David's action in response to the famine in 2 Sam 21:1-to "inquire of YHWH" (ויבקש דוד את פני יהוה) - is a common trope in times of disaster, and thus we have two of the three most common and essential elements of the Greek bone transfer narrative already at this point in the story (some disaster or need, followed by oracular inquiry). ${ }^{39}$ The "seeking" action implied by the verb בקש here, combined with פני יהוה (literally, "the face[s] of YнWH"), implies a cultic context, in a temple or from some intermediary (see, e.g., Hos 5:15; 2 Chr 7:14). ${ }^{40}$ The oracular answer from YHWH points directly to Saul's alleged mistreatment of the Gibeonites, a group of "resident aliens" (גרים) who had gained legal access to the land through deception during the conquest (see Joshua 9). גרים As, the Gibeonites may have been legally prevented from seeking financial redress for the wrong done to them (2 Sam 21:4), the payment of human life thus being the only available option serious enough to address the issue. ${ }^{42}$

After the killings are accomplished, the mother of two of the victims, Rizpah, embarks upon a mourning ritual in which she protects the bodies from defilement. The reported length of the vigil may have been as long as April-November (i.e., from the beginning of the harvest until the winter rains), unless the phrase "water poured out from the sky" in 2 Sam 21:10 refers to late spring rains. ${ }^{43}$ Whether her vigil lasted an extraordinary six to seven months or only a few days or weeks, her

308-9). He thus assumes the cause of the famine referenced in 2 Sam 21:1 is the burial status of Saul's and Jonathan's bodies away from the family tomb (ibid., 313 n. 32). On the contrary, the narrator explicitly tells us that it is bloodguilt incurred from killing the Gibeonites that causes the problem, though one can appeal, as Buttenwieser does, to two competing sources in this account (e.g., one detailing the Gibeonite problem and another regarding the famine itself). See also Raúl Quiroga, "La venganza gabaonita a la luz de los conceptos actuales de justicia. Un estudio interpretativo de 2 Samuel 21:1-14," DavarLogos 4 (2005) 117-29.

${ }^{39}$ Malamat finds in a fourteenth-century B.C.E. Hittite text a pattern of a covenant being broken in a past era, which results in a current situation of plague ("Doctrines of Causality"). The Hittite story does not, however, involve a bone transfer of any kind; rather, the attempt to remedy the situation comes through a formal apology for the past injustice. For the text, see "Plague Prayers of Muršili II," translated by Gary Beckman (COS 1.60:156-60).

${ }^{40}$ Hans W. Hertzberg embarks on an extended discussion of the issue and provides some oblique evidence that the site of the inquiry was the Gibeonite high place/sanctuary (see $1 \mathrm{Kgs} 3: 4 ; I$ \& II Samuel [trans. John Bowden; OTL; London: SCM Press, 1964] 382-83). See also the discussion in McCarter (II Samuel, 440), with reference to O. García de la Fuente, "David buscó el rostro de Yahweh (2 Sam 21,1)," Aug 8 (1968) 477-540.

${ }^{41}$ See, e.g., Jehoshua M. Grintz, "The Treaty of Joshua with the Gibeonites," JAOS 86 (1966) $113-26$.

${ }^{42}$ See Blenkinsopp, Gibeon and Israel, 34, 136 n. 31; McCarter, II Samuel, 441-42. See also Baruch Halpern, David's Secret Demons: Messiah, Murderer, Traitor, King (Grand Rapids: Eerdmans, 2001) 302-7 on David and the Gibeonite question.

${ }^{43}$ If the famine was in fact caused by a drought, then the presence of the rain here may signal the end of the natural disaster, and thus Rizpah's ritual ends when the problem is solved, prompting David to begin his response with the dead bodies. 
actions seem to motivate David's pity in 2 Sam 21:11, where the narrator explicitly connects David's cognizance of Rizpah's ritual with the reburial effort. To be sure, there is a strong element of shame here for David; the exposed bodies can only reflect badly on the new king in the eyes of any remaining supporters of the Saulide regime, perhaps even garnering sympathy for the fate of Saul's house from those who would not be predisposed to feel this way initially. David's response, in this light, seems non-optional and cannot simply or solely be described as a "personal gesture" of sympathy or other private emotion. ${ }^{44}$ It is also important to note that the recovery of the bones entails a long-distance procession, some 80 kilometers from Jabesh Gilead (east of the Jordan River) all the way down to Gibeah (or, more precisely, to the region of Zela just east of Gibeah). ${ }^{45}$ The final resting place of Saul's bones, then, ends up being only around three to five kilometers away from both David's capital in Jebus/Jerusalem and the territory of Gibeon, while at the same time the bones rest safely within Saul's own home. ${ }^{46}$ Moreover, David's reclamation of the bones from a territory that had been demonstrably hostile to his own claims of national power should be viewed as an assertion of political dominance that presumably ended in a sort of "truce" between David and the

${ }^{44}$ Cf. Chavel, "Compositry and Creativity," 39.

${ }^{45}$ McCarter assumes that David can only retrieve ashes and not bones in 2 Sam 21:12-14, since in 1 Sam 31:12-13 we are told that the residents of Jabesh burned the remains (II Samuel, 443). Cremation seems not to have been a typical Israelite burial practice, and it may be that only the rotted flesh was burned away or even that some memorial fire was lit for the dead. On the location of Jabesh Gilead, see Nelson Glueck, "Jabesh-Gilead," BASOR 89 (1943) 2-6.

${ }^{46}$ To be sure, as I will note below, the transfer can simultaneously be viewed as a normal placement of the body in Saul's patrimonial burial plot; see, e.g, Herbert C. Brichto, "Kin, Cult, Land and Afterlife-A Biblical Complex," HUCA 44 (1973) 1-54. The import of burying a charged figure such as Saul should not, of course, go unnoticed. I am inclined to agree with Rachel Hallote, who has recently declared that the Israelite "cult of the dead" was "one of the most active domestic cults in the biblical period" (Death, Burial, and Afterlife in the Biblical World: How the Israelites and Their Neighbors Treated the Dead [Chicago: Dee, 2001] 54). See also Elizabeth Bloch-Smith, Judahite Burial Practices and Beliefs about the Dead (Sheffield: Sheffield Academic Press, 1992) 23. Reviews of this topic can be found in: Brian B. Schmidt, Israel's Beneficent Dead: Ancestor Cult and Necromancy in Ancient Israelite Religion and Tradition (Winona Lake, Ind.: Eisenbrauns, 1996) 132-73; Theodore J. Lewis, Cults of the Dead in Ancient Israel and Ugarit (HSM 39; Atlanta, Ga.: Scholars Press, 1989) 99-170; idem, "Dead, Abode of the," ABD 2:101-5; Klaas Spronk, Beatific Afterlife in Ancient Israel and in the Ancient Near East (AOAT 219; Kevelaer: Buzon \& Berker, 1986) 3-12, 25-53, 65-81, 237-43; Mark S. Smith and Elizabeth Bloch-Smith, "Death and Afterlife in Ugarit and Israel," JAOS 108 (1988) 277-84; Karel van der Toorn, Family Religion in Babylonia, Syria, and Israel: Continuity and Change in the Forms of Religious Life (Studies in the History and Culture of the Ancient Near East 7; Leiden: Brill, 1996) 206-35. These views represent the dominant, current approach to the question, though there have been notable dissenters from this position: e.g., Philip S. Johnston, Shades of Sheol: Death and Afterlife in the Old Testament (Downers Grove, Ill.: InterVarsity, 2002) 70; and Schmidt, Israel's Beneficent Dead, 274, 282. Jon D. Levenson argues for a deeply rooted ancient Israelite belief in life after death but does not think death cults were as prevalent or influential as do many other recent interpreters (Resurrection and the Restoration of Israel: The Ultimate Victory of the God of Life [New Haven, Conn.: Yale University Press, 2006] 60-63). 
Gileadites, much in the same way that the Spartan theft of Orestes's bones from Tegea marked a similar dynamic. ${ }^{47}$

David's action thus serves several important purposes in mediating political strife. He solves both the Gibeonite problem and the problem of Saul's survivingand possibly rival—heirs, while simultaneously honoring Saul and his family with the patrimonial burial at Saul's home in Gibeah. The political implication of bone transferal, viewed through the lens of the Greek examples, adds nuance to Kyle McCarter's already well-established view of the so-called "History of David's rise" in 1 Samuel 16-2 Samuel $5^{48}$ as an Israelite example of the genre of Near Eastern royal apology comparable in narrative style to the thirteenth-century B.C.E. Hittite "Apology of Hattušili." "The author of 1-2 Samuel goes to great lengths to show David's innocence and deference toward Saul and Saul's family, while at the same time David engages in actions that can be interpreted as shrewdly advancing his own progress up the political ladder toward the kingship (e.g., marrying the king's daughters, preparing to fight for opposing armies against Israel [1 Sam 28:1-2; 29:1-11], garnering a private army, and establishing a rival capital). In the story involving Abner and Ishbaal referenced earlier (in 2 Samuel 3-4), we find another instance of David using this strategy of political murder and reburial; after Ishbaal is killed by David's men — and recall that Ishbaal's death formally cleared the way for David to become king-David enacts a kind of bone transfer for his rival to a family tomb at Hebron (or rather, a head transfer, as it is only the decapitated head that is reburied [2 Sam 4:12]). The pattern here, when compared with the treatment of the bones in 2 Sam 21:13-14, suggests a conscious political program, by which David marshals the power of the bodies of his rivals, treating them like allies and thereby attempting to neutralize the criticism that David himself has orchestrated all of the killings in question.

On the level of literary and cultural symbol, the dismemberment of Saul's body in 1 Samuel 31 signals an inexorable fissure in the leadership of the country; Saul has been decisively cut off from his people and his position of power. ${ }^{50}$ David's reclamation of the bones, then, signals his authority over a newly stabilized nation.

\footnotetext{
${ }^{47}$ As discussed by McCauley ("Heroes and Power," 88-89), the Tegean surrender of the bones could also be read as a conciliatory gesture of peace toward Sparta, and it is certainly possible that the interaction between Jabesh Gilead and David operated with a similar tension between national reconciliation and lasting hostilities.

${ }^{48}$ First identified as such by Leonhard Rost, Die Überlieferung von der Thronnachfolge Davids (BWANT 42; Stuttgart: Kohlhammer, 1926).

${ }^{49}$ In both documents, we find a historical narrative bent on showing divine guidance leading the future king along the path toward eventual rebellion and success against the current ruling powers (McCarter, I Samuel, 29-30). See "Apology of Hattušili III," translated by Theo P. J. van den Hout (COS 1.77:199-204).

${ }^{50}$ A similar observation is made by Michael Bryson, "Dismemberment and Community: Sacrifice and the Communal Body in the Hebrew Scriptures," Religion \& Literature 35 (2003) 1-21, at 14. Note also the symbol of tearing Saul's royal garment in 1 Sam 15:26-28, which operates on the same
} principle. 
The incident reminds us that Israel's early monarchy was a dangerously fragile affair, and indeed, monarchic rule did not trump tribal factions, which were never truly dissolved. Such a situation leaves David in a difficult position whenever rival claims arise - such as those between Saulides and Gibeonites in this instance. The two parts of the bone transfer drama here match the real, historical dual threats facing the early Israelite monarchy: threat from surrounding powers striving for regional hegemony (the Bible seems to imagine the Philistines as the primary enemy in this role ${ }^{51}$ ) and threat from within the nation itself, born from the ethnic patchwork of nascent Israel.

\section{Conclusion}

I hope to have shown, at least partially, some avenues by which the trope of bone transferal and heroic power can be explored in the biblical texts that recount the journeys of Saul's body. To summarize, Saul's bone transfer can be compared to the Greek materials on several fronts: a crisis prompts an oracular inquiry, which leads to the retrieval of the bones of a hero and the relocation of those bones, upon which a resolution to disaster then follows. Beyond these bare correspondences of plot, moreover, we have found serious political implications present in David's actions, and the value of the comparison here is that the Greek materials alert us to the presence of these types of motives hidden just below the surface of the text, which are often overlooked by biblical interpreters when reading this particular narrative. There are nonetheless clear differences between the biblical story here and the Greek bone transfer accounts: the oracle David receives (as we now have it in the text) does not specifically stipulate the retrieval of Saul's-or anyone else's-bones but rather points only to the cause of the famine, and thus the bone transfer is a corollary, not the main act in the drama..$^{52}$

Nevertheless, the basic outline of the comparison and some of its specificities are compelling and suggest that we posit some sort of Mediterranean koine of heroic ideology and bone transfer ideology that became visible in Israel by at least the eighth to the sixth centuries B.C.E. ${ }^{53}$ The place of the bone transfer narrative

${ }^{51}$ See Peter Machinist, "Biblical Traditions: The Philistines and Israelite History," in The Sea Peoples and Their World: A Reassessment (ed. Eliezer D. Oren; University Museum Monograph 108; University Museum Symposium Series 11; Philadelphia: University Museum, University of Pennsylvania, 2000) 53-83, esp. 64-69.

${ }^{52}$ However, based on the parallel texts involving heroic body transfer, one may speculate that just such a command, through the oracle, had indeed been offered but is no longer a part of the text as we have it. The Israelite focus on issues of defilement and honor regarding bodies-enhanced in the case of heroic or important bodies-suggests that the role of the body transfer was nevertheless an important one.

${ }^{53}$ This language of a "Mediterranean koine" has also been recently invoked by Corinna Riva, "The Culture of Urbanization in the Mediterranean c.800-600 BC," in Mediterranean Urbanization 800-600 BC (ed. Robin Osborne and Barry Cunliffe; Proceedings of the British Academy 126; Oxford: Oxford University Press, 2005) 203-32, at 203-4. Riva states that "one may ... define this koine as international. At the same time, the modes of its reception were geographically specific, giving rise 
in the ongoing lives of certain prominent Greek heroes militates against Mobley's argument that the heroic life of Saul does not have "a heroic conclusion." ${ }^{54}$ On the contrary, he shares the heroic fate of Oedipus, Theseus, Orestes, and others when his bones are transferred as an object of power and political manipulation, and thus the Deuteronomist has preserved an echo of Saul's heroic identity even in the tragic tale of his death. The hero in ancient Mediterranean literature is a profoundly unstable individual; as Nagy puts it in his seminal study, the hero is antagonistic to the god who is most like him or her in life, and only in death is the enduring fame (Greek kleos) of the hero solidified through appropriate funerary ritual..$^{55}$

Perhaps more than any other character in the Hebrew Bible, Saul embodies this very process. Something in the order of the divine and earthly cosmos is rectified when Saul's body returns home under David's protective care, and the story of Saul, which stretches a narrative distance in 1-2 Samuel longer than David's own presence, finally ends only with the return of Saul's bones. Just as Saul thought he could be rid of his most difficult antagonist, the prophet Samuel, and yet Samuel reached him from beyond the grave (1 Samuel 28), so too does Saul's memory and power continue to haunt and manipulate David, even as David seeks in a final gesture to control a scenario of frightening political upheaval with Saul's own body. The story of bone transferal I have tried to tell here is thus about David in every way, but it is also about the ongoing symbol of cult and politics embodied in Saul's bones and all that Saul represented as both victor and victim throughout 1-2 Samuel: not simply a faulty, defunct, rejected chieftain but rather an object of power, a standard of YHWH's election in the past as Israel's first king.

to local interpretations and meanings which individual groups assigned to it" (ibid., 203 [italics in original]).

${ }^{54}$ Mobley, "Glimpses of Heroic Saul," 80. Preston contrasts Saul's tragic, heroic death on the battlefield with David's slow decline in bed in 1 Kings ("Heroism of Saul," 37-38, 41-44). Preston even goes so far as to say that Saul's death is "in defense of Israel," while David dies "in his bed with the moral fabric of Israel crumbling around him" ("Heroism of Saul," 44).

${ }^{55}$ Nagy, Best of the Achaeans, 67-210. 